\title{
ANALYSIS OF INTERACTIVE CONTROL SYSTEM ON CORPORATE SUSTAINABILITY PERFORMANCE: GOOD CORPORATE GOVERNANCE AS A MEDIATING VARIABLE
}

\author{
Wijaya Triwacananingrum \\ Pelita Harapan University (UPH) \\ wijaya_nining@yahoo.com
}

Received: 17-03-2018

Revised: 29-03-2018

Accepted: 10-09-2018

\section{ABSTRACT}

The purpose of this research is to test how the measurement of interactive control system can improve corporate sustainability performance through good corporate governance. This research was employed through a survey involving the decision makers of Echelon-2 and higher levels as the research subjects in one leading cement industry in Indonesia, Semen Indonesia by distributing questionnaires. The data were analyzed through structural equation modeling. Measurement model was to test reliability and validity, while the structural measurement model was measured by the mean $\mathrm{R}^{2}$ for the dependent variable and the path coefficient test. Of the thirty-nine questionnaires collected, thirty-three questionnaires were eligible for further processing. The results shows positive relationship between interactive control on corporate governance, negative relationship between corporate governance to corporate sustainability performance, and positive relationship between interactive control and corporate sustainability performance. The interactive control system can directly improve the corporate sustainability performance, while good corporate governance cannot mediate the relationship between interactive control system and corporate sustainability performance.

Keywords: Corporate Sustainability Performance; Good Corporate Governance; Interactive Control System; Semen Indonesia.

How to cite: Triwacananingrum, W. (2018). Analysis Of Interactive Control System On Corporate Sustainability Performance: Good Corporate Governance As A Mediating Variable. Akrual: Jurnal Akuntansi. 10 (1): 47-56. doi: http://dx.doi.org/10.26740/jaj.v10n1.p47-56

\section{INTRODUCTION}

Interactive control system in accounting management has close relation with management control systems that may help the companies to control the activities of the companies and individuals as it is outlined previously (Otley \& Berry, 1994). Some previous researchers have investigated how the relationship between interactive performance measurement and organizational performance (Bisbe \& Otley, 2004; Chenhall, Kallunki, \& Silvola, 2011; Naranjo-Gil \& Hartmann, 2007a, b). In contrast to previous research, this study is intended to examine how interactive performance measurement may improve the corporate sustainability performance through good corporate governance. It is assumed that with a very tight business competition, companies are expected to have intention to improve their corporate governance in order to achieve sustainability competitive advantage. Study in this issue is still considered difficult to identify.

It is assumed that interactive control systems may improve good corporate governance. Furthermore, good corporate governance may improve corporate sustainability performance. The effectiveness of the application of interactive control systems occurs when there is an intensity of 
communication between superiors and subordinates on issues that occur in achieving both organizational and individual goals. These issues may occur in a relatively dynamic business environment. One of the effects of communication between the superiors and subordinates is to increase information openness, which ultimately may encourage the accountability and transparency in the process of decision-making among the employees, including managers and staffs in the company. In other words, the existence of such openness is expected to improve good corporate governance in the company.

It is believed that the aspects of good corporate governance are essential elements in business continuity. One example of researches carried out by Peni \& Vähämaa (2011) on banking companies in the US during the 2008 financial crisis shows that companies that implement good corporate governance are more immune to the monetary crisis that occurred at that time. The performance of the companies with strong corporate governance will be able to: (1) obtain higher profits, (2) have higher market valuations, and (3) receive fewer negative impacts related to the monetary crisis on stock returns. Based on these indicators, it can be concluded that good corporate governance are able to improve the corporate sustainability performance. Based on the description above, a study in the area of interactive control system analysis needs to be conducted on the corporate sustainability performance, with good corporate governance is employed as the mediating variable.

Based on the introduction, there are some issues in this study, namely:

a. Does interactive control have positive relationship with corporate governance?

b. Does corporate governance have positive relationship with corporate sustainability?

c. Does interactive control have positive relationship with corporate sustainability?

Based on the issues stated on the previous section, the objectives of this study are to test the following issues, namely:

a. Does interactive control have positive relationship with corporate governance?

b. Does corporate governance have positive relationship with corporate sustainability?

c. Does interactive control have positive relationship with corporate sustainability?

\section{LITERATURE REVIEW}

\section{Interactive Control System}

The interactive control system may give more benefits in strategic changes at high levels of environmental uncertainty. Strategic changes may occur in dynamic circumstances as the interactive control system are able to facilitate learning and innovation (Simons, 2000). The use of interactive control systems is also to accommodate the managers in stimulating learning and innovation through dialogues and communications among the organizational members, of which is expected to improve the process of developing the organizational strategy (Kaplan \& Norton, 1996, 2006; Simons, 1990, 1991, 2000). Thus, this performance appraisal system will actively stimulate debate and discussion for activities that have been and will be conducted (Bisbe \& Malagueño, 2009; Burchell, Clubb, Hopwood, 
Hughes, \& Nahapiet, 1980; Chenhall et al., 2011).

\section{Corporate Sustainability Performance}

A company is sustainable if the company is able to create benefits for its stakeholders while protecting the environment and improving the lives of those who interact with it at the same time (Svensson, Wagner, Cambra-Fierro, \& Ruiz-Benitez, 2011). There are four aspects of corporate sustainability: (1) social impact, (2) environmental impact, (3) cultural aspect, and (4) organizational funding (Crowther, 2008). Despite the fact that the developing control mechanisms to support the implementation of sustainability strategies sometimes receives skepticism and highlighted in several literatures (Mersereau \& Mottis, 2011), however, some of the controls being observed are the main mechanisms, and most sample companies have not developed a complete accounting control package; these controls generally remain separate from the management control system "package" used to manage the organization (Crutzen, Swank, \& Visser, 2013). The extent to which it is possible to influence sustainability at the operational level by contemporary management control systems in integrating organizational culture perspectives (Morsing, \& Oswald, 2009)

\section{Good Corporate Governance}

The objectives of Law on Limited Liability Company number 40 of 2007 Articles 66 and 74 are used as the driver for the implementation of good corporate governance
(GCG) in addition to encouraging the practice and disclosure of corporate social responsibility (CSR) (Djamilah \& Trenggono, 2017). By applying GCG practices, it is expected that the company will be able to increase investors' confidence, thus the company will also be more stable and stronger which in turn the sustainability of the company can be relied upon. This is in accordance with the Decree of the Minister of State-Owned Enterprises number 117/M-MBU of 2002 on corporate governance which is a process and structure used by an state-owned enterprises (SOEs) organ to increase business success and corporate accountability to realize the interests of other stakeholders, based on legislation and ethical values.

According to Simons (1995) that the interactive control system is very good at helping organizations to improve the performance of a company. An interactive performance measurement system occurs when there is a flow of communication that is carried out regularly between the managers and subordinates (Abernethy \& Brownell, 1999; Adler \& Chen, 2011; Bisbe, BatistaFoguet, \& Chenhall, 2007; Henri, 2006; Simons, 1995). The advantage of using an interactive performance measurement system is that the manager may deliver messages to all members of the organization to concentrate on various strategic issues and environmental uncertainties (Triwacananingrum \& Yuliansyah, 2016).

Interactive performance evaluation can be done with some communication approaches such as discussions, meetings and even 
debates, so that the process being conducted automatically will be able to stimulate information sharing among members of the organization. By sharing the information may also create accountable and transparent information, encouraging the company to create good corporate governance. Thus interactive control is believed to improve good corporate governance.

As is known that good corporate governance is an important indicator in business continuity. Companies that implement good corporate governance are likely able to maintain their business continuity. Based on this description, the conceptual framework can be described as follows:

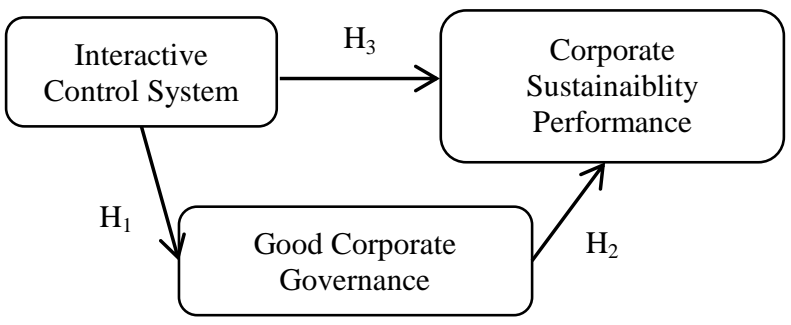

Figure 1: Conceptual Framework

Based on the above preposition, there are three hypotheses proposed in this study:

\section{$H_{1}$ : there is positive relation between interactive control and corporate governance}

$\mathrm{H}_{2}$ : there is positive relation between corporate governance and corporate sustainability

$H_{3}$ : there is positive relation between interactive control and corporate sustainability

\section{RESEARCH METHODS}

This is a survey study involving relevant decision makers at the Echelon-2 level and above at one leading cement industry in Indonesia, Semen Indonesia Group. The survey was carried out by distributing questionnaires to the mentioned relevant decision makers. To increase the response rate, several methods were employed by the researchers, namely questionnaire design/questionnaire preparation and questionnaire delivery. In preparing the questionnaire, a booklet-shaped questionnaire with double-sided printing layouts (Dillman, 1972) was distributed. This design is believed to increase the response rate from the participants. Jobber (1989, p. 137) says that "interpretation of this result is that doublesided printing makes the questionnaire appear shorter and thus less time-consuming than single-sided printing".

In addition to the questionnaire design, just as Henri (2006) did, researchers also used four steps of survey implementation, namely initial communication, first and second followups. The initial communication was taken by a researcher to confirm whether the respondents were interested in being involved in the research and asking how many questionnaires could be handled and sent. Initial communication was done via text-messaging and telephoning. As the respondents showed their interests on being involved in the study, first follow-up was carried out by posting the questionnaire as well as envelopes that had been given return-stamps to send back the questionnaires that had been filled out. In addition, second follow-up was done through telephoning which was intended to remind the respondents to fill out the questionnaires. 
There are three variables in this study, namely: interactive control system, good corporate governance and corporate sustainability performance.

\section{Interactive Control System}

The interactive performance measurement system in this study employed a questionnaire which has previously been developed by Abernethy \& Brownell (1999). The questionnaire has been widely used by previous researchers in the related contexts (see Bisbe \& Otley, (2004); Bisbe \& Malagueño, (2009) and Naranjo-Gil \& Hartmann, (2007b). The questionnaire consisted of five questions asking the respondents about how important the respondents are to the performance evaluation. The questions were distributed into 6-point Likert scale that starts from 1 (corresponds very low) to 6 (corresponds very high).

\section{Good Corporate Governance}

Good corporate governance in this study used a questionnaire which was developed by the Indonesian Center for Social and Environmental Accounting Research and Development. The questionnaire consisted of four questions asking the respondents about how important the respondents are to performance evaluation. The questions were distributed into 6-point Likert scale that starts from 1 (corresponds very low) to 6 (corresponds very high).

\section{Corporate Sustainability Performance}

Corporate sustainability performance in this study used a questionnaire which was previously developed by the Indonesian Center for Social and Environmental Accounting. The questionnaire consisted of eight questions asking the respondents about how important the respondents are to performance evaluation. The questions were distributed into 6-point Likert scale that starts from 1 (corresponds very low) to 6 (corresponds very high).

\section{ANALYSIS AND DISCUSSION}

Data were analyzed by using structural equation model (SEM) with the rationale that "the ability to model multiple relationships is an advantage of latent variable SEM over multiple regression and path analysis" (Baines \& Langfield-Smith, 2003, p. 686). Likewise, SEM can examine simultaneously the measurement model and the structural model in the one model (Burton-Jones \& Hubona, 2006). In addition, partial least square (PLS) has an obvious advantage over regression for two reasons:

1. It considers all path coefficients simultaneously to allow the analysis of direct, indirect, and spurious relationships;

2. It estimates the individual item weightings in the context of the theoretical model rather than in isolation' (Birkinshaw, Morrison, \& Hulland, 1995, p.647).

Smith \& Langfield-Smith (2004) state that in analysis, SEM uses two steps, namely measurement model and measurement structural model. The measurement model is to test reliability and validity (Camisón \& López, 2010; Hulland, 1999). Reliability testing is done by analyzing Cronbach's alpha and 
composite reliability. In accordance with the rules used that as Cronbach's alpha is more than 0.7 , it shows a good level of reliability (Hulland, 1999).

Testing the validity by using PLS can be done by convergent validity testing and discriminant validity. Convergent validity can be calculated by looking at the Average Variance Extracted (AVE) score. Henseler et al. (2009) said that the value of convergent validity is very good if the score of AVE is above 0.5 . The purpose of discriminant validity is to see whether the item is unique and not the same as other constructs in the model (Hulland, 1999). To test discriminant validity can be done by two methods, namely the Fornell-Larcker and the Cross-loading methods.

Fornell-Larcker method is done by comparing the square roots of AVE with vertical latent correlation, and the next method is the Cross-loading method which states that all items must be larger than other constructs (Al-Gahtani, Hubona, \& Wang, 2007).

Table 1. Quality Criteria

\begin{tabular}{lcccc}
\hline & AVE & $\begin{array}{c}\text { Composite } \\
\text { reliability }\end{array}$ & $\begin{array}{c}\mathrm{R} \\
\text { square }\end{array}$ & $\begin{array}{c}\text { Cronbach's } \\
\text { alpha }\end{array}$ \\
\hline $\begin{array}{l}\text { Interactive } \\
\text { control } \\
\text { sysem }\end{array}$ & 0.543 & 0.892 & & 0.858 \\
$\begin{array}{l}\text { Good } \\
\text { corporate } \\
\text { governance }\end{array}$ & 0.566 & 0.791 & 0.261 & 0.648 \\
$\begin{array}{l}\text { Corporate } \\
\text { sustainability } \\
\text { performance }\end{array}$ & 0.539 & 0.968 & 0.711 & 0.965 \\
\hline
\end{tabular}

\section{Source: Data process}

As shown in Table 2 in which the value of the construct correlation of GCG is higher than the valueof other constructs. As with other indicators that are higher correlated with their respective constructs compared to others, this means that the construct has a good discriminant validity value. In addition, it is also to see the square value of the correlation between constructs with AVE values or correlation between constructs and AVE roots.

Table 3 shows the maximum correlation of GCG constructs with other constructs of 0.752 while the minimum correlation is 0.511 . This shows that if each construct has a higher value than the other construct, this construct has a good discriminant validity value.

Structural measurement model is measured by the average $\mathrm{R}^{2}$ for the dependent variable and path coefficient testing. According to Camisón \& López (2010) that if the value of $\mathrm{R}^{2}$ is greater than 0.1 , it can be accepted. This test is carried out using a bootstrap procedure with 500 replacements (e.g. Hartmann \& Slapnicar, 2009).

Table 2. Cross Loading

\begin{tabular}{lccc}
\hline & GCG & Interactive & Sustainability \\
\hline CG 2 & $\mathbf{0 . 9 1 9}$ & 0.532 & 0.600 \\
CG 3 & $\mathbf{0 . 6 2 3}$ & 0.076 & 0.201 \\
CG 4 & $\mathbf{0 . 6 8 1}$ & 0.345 & 0.283 \\
IC 2 & 0.283 & $\mathbf{0 . 6 0 4}$ & 0.585 \\
IC 7 & 0.347 & $\mathbf{0 . 8 0 8}$ & 0.590 \\
IC 8 & 0.290 & $\mathbf{0 . 7 6 6}$ & 0.645 \\
IC 9 & 0.552 & $\mathbf{0 . 7 6 7}$ & 0.556 \\
IC 11 & 0.314 & $\mathbf{0 . 7 3 0}$ & 0.645 \\
IC 12 & 0.257 & $\mathbf{0 . 6 9 4}$ & 0.662 \\
IC 13 & 0.546 & $\mathbf{0 . 7 6 9}$ & 0.595 \\
SP 1 & 0.324 & 0.584 & $\mathbf{0 . 6 9 7}$ \\
SP 2 & 0.431 & 0.513 & $\mathbf{0 . 6 9 0}$ \\
SP 3 & 0.353 & 0.521 & $\mathbf{0 . 6 7 3}$ \\
SP 4 & 0.487 & 0.681 & $\mathbf{0 . 7 3 8}$ \\
SP 5 & 0.432 & 0.686 & $\mathbf{0 . 8 3 9}$ \\
SP 6 & 0.302 & 0.619 & $\mathbf{0 . 6 6 0}$ \\
SP 7 & 0.395 & 0.729 & $\mathbf{0 . 8 2 8}$ \\
SP 8 & 0.208 & 0.429 & $\mathbf{0 . 4 9 7}$ \\
SP 9 & 0.372 & 0.739 & $\mathbf{0 . 7 7 8}$ \\
SP 10 & 0.473 & 0.790 & $\mathbf{0 . 8 2 9}$ \\
SP 11 & 0.571 & 0.753 & $\mathbf{0 . 8 1 2}$ \\
SP 12 & 0.353 & 0.602 & $\mathbf{0 . 7 7 3}$ \\
SP 13 & 0.341 & 0.547 & $\mathbf{0 . 6 7 9}$ \\
SP 14 & 0.500 & 0.670 & $\mathbf{0 . 7 1 3}$ \\
SP 16 & 0.321 & 0.539 & $\mathbf{0 . 6 4 7}$ \\
SP 17 & 0.268 & 0.575 & $\mathbf{0 . 6 4 8}$ \\
SP 18 & 0.283 & 0.449 & $\mathbf{0 . 7 0 7}$ \\
SP 19 & 0.341 & 0.492 & $\mathbf{0 . 6 7 4}$ \\
SP 20 & 0.430 & 0.636 & $\mathbf{0 . 8 1 9}$ \\
SP 22 & 0.443 & 0.658 & $\mathbf{0 . 7 7 5}$ \\
SP 25 & 0.447 & 0.562 & $\mathbf{0 . 7 0 1}$ \\
SP 26 & 0.402 & 0.343 & $\mathbf{0 . 6 6 3}$ \\
SP 27 & 0.470 & 0.560 & $\mathbf{0 . 7 4 5}$ \\
SP 28 & 0.559 & 0.642 & $\mathbf{0 . 8 3 2}$ \\
SP 29 & 0.463 & 0.667 & $\mathbf{0 . 8 4 3}$ \\
SP 30 & 0.448 & 0.507 & $\mathbf{0 . 7 1 1}$ \\
\hline D Data & process & &
\end{tabular}

Source: Data process 
Table 3. Fornell-Larcker

\begin{tabular}{lccc}
\hline & GCG & Interactive & Sustainability \\
\hline GCG & $\mathbf{0 , 7 5 2}$ & & \\
Interactive & 0,511 & $\mathbf{0 , 7 3 7}$ & \\
Sustainability & 0,556 & 0,829 & 0,734 \\
\hline
\end{tabular}

Source: Data process

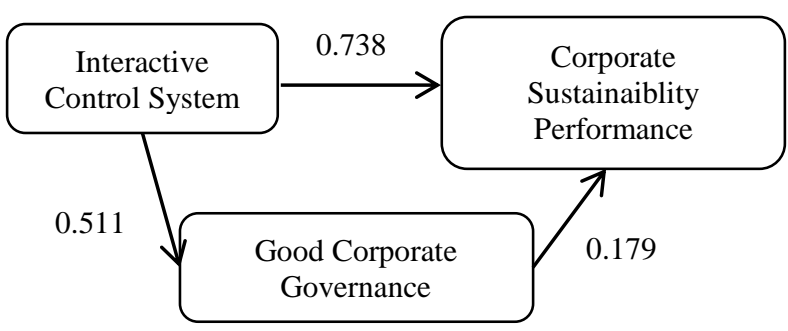

Figure 2. Structural Equation Model (SEM)

Table 4. Structural Measurement Model

\begin{tabular}{lccc}
\hline \multirow{2}{*}{$\begin{array}{c}\text { Dependent } \\
\text { variables }\end{array}$} & $\begin{array}{c}\text { Interactive } \\
\text { control } \\
\text { system }\end{array}$ & $\begin{array}{c}\text { Good } \\
\text { corporate } \\
\text { governanc } \\
\mathrm{e}\end{array}$ & \\
\hline $\begin{array}{l}\text { Good corporate } \\
\text { governance }\end{array}$ & $\left(4.545^{* * *}\right)$ & & 0.261 \\
$\begin{array}{l}\text { Corporate } \\
\text { sustainability }\end{array}$ & $\left(6.924^{* * *}\right)$ & $(-1.325)$ & 0.711 \\
\hline
\end{tabular}

Source: Data process

\section{$\mathrm{H}_{1}$ : There is positive relation between interactive control and corporate governance.}

In Table 4 shows the positive relation of interactive control to the corporate governance with the significant score of $(\beta=0.511, t=$ $4.545, \mathrm{p}<0.01)$. As the t-statistic is on the critical score of 2.303, thus $\mathrm{H}_{1}$ is supported.

\section{$\mathrm{H}_{2}$ : There is positive relation between corporate governance and corporate sustainability performance.}

In Table 4 shows the negative relation of corporate governance to corporate sustainability performance with the score of $(\beta=0.179, t=-1.325, p<0.1)$. As the $t$-statistic is under the critical score of 1.600 , thus $\mathrm{H}_{2}$ is not supported.

\section{$\mathrm{H}_{3}$ : There is positive relation between interactive control and corporate sustainability performance.}

In Table 4 shows the positive relation of interactive control to corporate sustainability performance with the score of $(\beta=0.738, t=$ 6.924, $\mathrm{p}<0.01)$. As the t-statistic is above the critical score of 2.303, thus $\mathrm{H}_{3}$ is supported.

\section{CONCLUSION}

The involvement of managers and subordinates/staffs in the process of achieving organizational goals may lead into information openness that may encourage better accountability and transparency in the process of decision-making between the managers and employees in a company. This involvement may also provide more benefits in terms of strategic changes at a high level of environmental uncertainty. Strategic changes may take place dynamically as the interactive control system facilitates learning and innovation through two-way communications among the members of an organization (a company) that may improve the development process of each organization which can ultimately improve good corporate governance.

In order to answer the research objectives, a survey was carried out involving Echelon-2 level and above in one leading cement industry in Indonesia, Semen Indonesia Group. Based on 39 questionnaires collected, 33 questionnaires were analyzed $(85 \%)$ and considered valid that had been tested using SmartPLS 3.0. Based on the results of calculations, the interactive control system may directly improve corporate sustainability performance, while good corporate governance may not mediate the 
relationship of interactive control systems and corporate sustainability performance.

This research is limited to sampling, which was only at one cement industry, Semen Indonesia Group that have not been able to describe the actual state of the entire companies thoroughly. In addition, the mediation variable used in this study is only good corporate governance so that it cannot fully describe the factors that can mediate interactive control systems and the sustainability of corporate performance.

The implication of this research is that the interactive control system is a very necessary aspect in a company because it is believed to improve good corporate governance and corporate sustainability performance. For companies in industrial sector, sharing information in an interactive performance evaluation may create more accountable and transparent information. Accountable and transparent information encourages companies to create good corporate governance as well as corporate sustainability governance.

\section{REFERENCES}

Abernethy, M. A., \& Brownell, P. (1999). The role of budgets in organizations facing strategic change: an exploratory study. Accounting, Organizations and Society, 24(3), 189-204. doi:10.1016/s03613682(98)00059-2

Adler, P. S., \& Chen, C. X. (2011). Combining Creativity and Control: Understanding Individual Motivation in Large-Scale Collaborative Creativity. SSRN Electronic Journal. doi:10.2139/ssrn.1471341
Al-Gahtani, S. S., Hubona, G. S., \& Wang, J. (2007). Information technology (IT) in Saudi Arabia: Culture and the acceptance and use of IT. Information \& Management, 44(8), 681-691. doi:10.1016/j.im.2007.09.002

Baines, A., \& Langfield-Smith, K. (2003). Antecedents to management accounting change: a structural equation approach. Accounting, Organizations and Society, 28(7-8), 675-698. doi:10.1016/s03613682(02)00102-2

Birkinshaw, J., Morrison, A., \& Hulland, J. (1995). Structural and competitive determinants of a global integration strategy. Strategic Management Journal, 16(8), 637-655. doi:10.1002/smj.4250160805

Bisbe, J., Batista-Foguet, J.-M., \& Chenhall, R. (2007). Defining management accounting constructs: A methodological note on the risks of conceptual misspecification. Accounting, Organizations and Society, 32(7-8), 789820. doi:10.1016/j.aos.2006.09.010

Bisbe, J., \& Malagueño, R. (2009). The Choice of Interactive Control Systems under Different Innovation Management Modes. European Accounting Review, 18(2), 371-405. doi:10.1080/09638180902863803

Bisbe, J., \& Otley, D. (2004). The effects of the interactive use of management control systems on product innovation. Accounting, Organizations and Society, 29(8), 709-737. doi:10.1016/j.aos.2003.10.010

Burchell, S., Clubb, C., Hopwood, A., Hughes, J., \& Nahapiet, J. (1980). The roles of accounting in organizations and society. Accounting, Organizations and Society, 5(1), 5-27. doi:10.1016/03613682(80)90017-3

Burton-Jones, A., \& Hubona, G. S. (2006). The mediation of external variables in the technology acceptance model. Information \& Management, 43(6), 706717. doi:10.1016/j.im.2006.03.007 
Cambra-Fierro, J., \& Ruiz-Benítez, R. (2011). Sustainable business practices in Spain: a two-case study. European Business Review, 23(4), 401-412. doi:10.1108/09555341111145780

Camisón, C., \& Villar López, A. (2010). An examination of the relationship between manufacturing flexibility and firm performance. International Journal of Operations \& Production Management, 30(8), 853-878. doi:10.1108/01443571011068199

Chenhall, R. H., Kallunki, J.-P., \& Silvola, H. (2011). Exploring the Relationships between Strategy, Innovation, and Management Control Systems: The Roles of Social Networking, Organic Innovative Culture, and Formal Controls. Journal of Management Accounting Research, 23(1), 99-128. doi:10.2308/jmar-10069

Crowther, D. (2008). Corporate Social Responsibility: Bookboon.

Crutzen, B. S. Y., Swank, O. H., \& Visser, B. (2013). Confidence Management: On Interpersonal Comparisons in Teams. Journal of Economics \& Management Strategy, 22(4), 744-767. doi:10.1111/jems.12037

Djamilah, S., \& Surenggono, S. (2017). Corporate Social Responsibility Sebagai Variabel Pemediasi Pengaruh Good Corporate Governance Terhadap Kinerja Keuangan. AKRUAL: Jurnal Akuntansi, 9(1), 41. doi:10.26740/jaj.v9n1.p41-53

Dillman, D. A. (1972). Increasing Mail Questionnaire Response in Large Samples of the General Public. Public Opinion Quarterly, 36(2), 254. doi:10.1086/267997

Hartmann, F., \& Slapničar, S. (2009). How formal performance evaluation affects trust between superior and subordinate managers. Accounting, Organizations and Society, 34(6-7), 722-737. doi:10.1016/j.aos.2008.11.004

Henri, J.-F. (2006). Management control systems and strategy: A resource-based perspective. Accounting, Organizations and Society, 31(6), 529-558. doi:10.1016/j.aos.2005.07.001
Henseler, J., Ringle, C. M., \& Sinkovics, R. R. (Eds.). (2009). The Use of Partial Least Squares Path Modeling in International Marketing. Advances in Intenational Marketing, 20: 277-319.

Hulland, J. (1999). Use of Partial Least Squares (PLS) in Strategic Management Research: A Review of Four Recent. Strategic Management Journal, 20(2): 195. https://doi.org/10.1002

Jobber, D. (1989). An examination of the effects of questionnaire factors on response to an industrial mail survey. International Journal of Research in Marketing, 6(2), 129-140. doi:10.1016/0167-8116(89)90006-2

Kaplan, R. S., \& Norton, D. P. (1996). The Balanced Scorecard: Translating Strategy into Action Boston, MA: Harvard Business School Press.

Kaplan, R. S., \& Norton, D. P. (2006). Alignment - Using the Balanced Scorecard to Create Corporate Strategies. Boston, Massachusetts: Harvard Business School Press.

Kementrian Badan Usaha Milik Negara Republik Indonesia. (2017). Penerapan Praktek Good Corporate Governance pada Badan Usaha Milik Negara(KEP100/MBU/2002) http://jdih.bumn.go.id/

Mersereau, A., \& Mottis, N. (2011). Corporate Social Responsibility and Management Control. SSRN Electronic Journal. doi:10.2139/ssrn.2331990

Naranjo-Gil, D., \& Hartmann, F. (2007a). How CEOs use management information systems for strategy implementation in hospitals. Health Policy, 81(1), 29-41. doi:10.1016/j.healthpol.2006.05.009

Naranjo-Gil, D., \& Hartmann, F. (2007b). Management accounting systems, top management team heterogeneity and strategic change. Accounting, Organizations and Society, 32(7-8), 735756. doi:10.1016/j.aos.2006.08.003 
Peni, E., \& Vähämaa, S. (2011). Did Good Corporate Governance Improve Bank Performance during the Financial Crisis? Journal of Financial Services Research, 41(1-2), 19-35. doi:10.1007/s10693-011$0108-9$

Simons, G. (1995). Beginnings. Korea, 63-88. doi:10.1007/978-1-349-23950-4_2

Simons, R. (1990). The role of management control systems in creating competitive advantage: New perspectives. Accounting, Organizations and Society, 15(1-2), 127-143. doi:10.1016/03613682(90)90018-p

Simons, R. (1991). Strategic orientation and top management attention to control systems. Strategic Management Journal, 12(1), 49-62. doi:10.1002/smj.4250120105

Shelleman, J. M., \& Shelleman, J. M. (1995). Levers of Control: How Managers Use Innovative Control Systems to Drive Strategic Renewal by Simons Robert, Boston, MA; Harvard Business School Press, 1995-215 pages, hard cover, $\$ 29.95$. Academy of Management Perspectives, 9(2), 82-84. doi:10.5465/ame.1995.9506273288

Otley, D. T., \& Berry, A. J. (1994). Case study research in management accounting and control. Management Accounting Research, 5(1), 45-65. doi:10.1006/mare.1994.1004

Simons, R. (2000). Performance Measurement and Control Systems for Implementing Strategy. New Jersey: Prentice-Hall.

Smith, D., \& Langfield-Smith, K. (2004). Structural Equation Modeling in Management Accounting Research: Critical Analysis and Opportunity. Journal of Accounting Literature, 23: 4989.

Svensson, G., \& Wagner, B. (2011). Transformative business sustainability. European Business Review, 23(4), 334352. doi:10.1108/09555341111145735

Cambra-Fierro, J., \& Ruiz-Benítez, R. (2011). Sustainable business practices in Spain: a two-case study. European Business Review, 23(4), 401-412. doi:10.1108/09555341111145780
Morsing, M., \& Oswald, D. (2009). Sustainable leadership: management control systems and organizational culture in Novo Nordisk A/S. Corporate Governance: The International Journal of Business in Society, 9(1), 83-99. doi:10.1108/14720700910936083 